\title{
ДО 25-РІЧЧЯ ЗАСНУВАННЯ ФАКУЛЬТЕТУ ПІДВИЩЕННЯ КВАЛІФІКАЦІЇ ВИКЛАДАЧІВ НАЦІОНАЛЬНОЇ МЕДИЧНОЇ АКАДЕМІЇ ПІСЛЯДИПЛОМНОЇ ОСВІТИ ІМЕНІ П. Л. ШУПИКА
}

\author{
О. П. Мінцер, Л. Ю. Бабінцева
}

Національна медична академія післядипломної освіти імені П. Л. Шупика

Відомо, що освіта, як сфера людської діяльності, перш за все спрямована на здобуття нових знань. Беззаперечним $є$ й той факт, що науковий підхід до всіх видів людської діяльності змушує освіту розвиватися швидшими темпами, ніж будь-яку іншу галузь діяльності, «...задовольняючи потреби суспільства та держави в технологічному розвитку шляхом взаємодії освіти та науки...» (Закон України «Про наукову і науково-технічну діяльність» від 26.11.2015 № 848-VIII).

Метою заснування першого в країні факультету підвищення кваліфікації викладачів (ПКВ), стала реалізація системного підходу до вдосконалення знань і підвищення кваліфікації науково-педагогічних працівників (НПП) системи післядипломної медичної освіти.

Серед основних завдань сучасного факультету ПКВ виділимо такі:

- створення принципово нового центру підвищення кваліфікації НПП;

- формування нових професійних компетентностей НПП;

- застосування інноваційних технологій для реалізації змісту навчання, що передбачає його
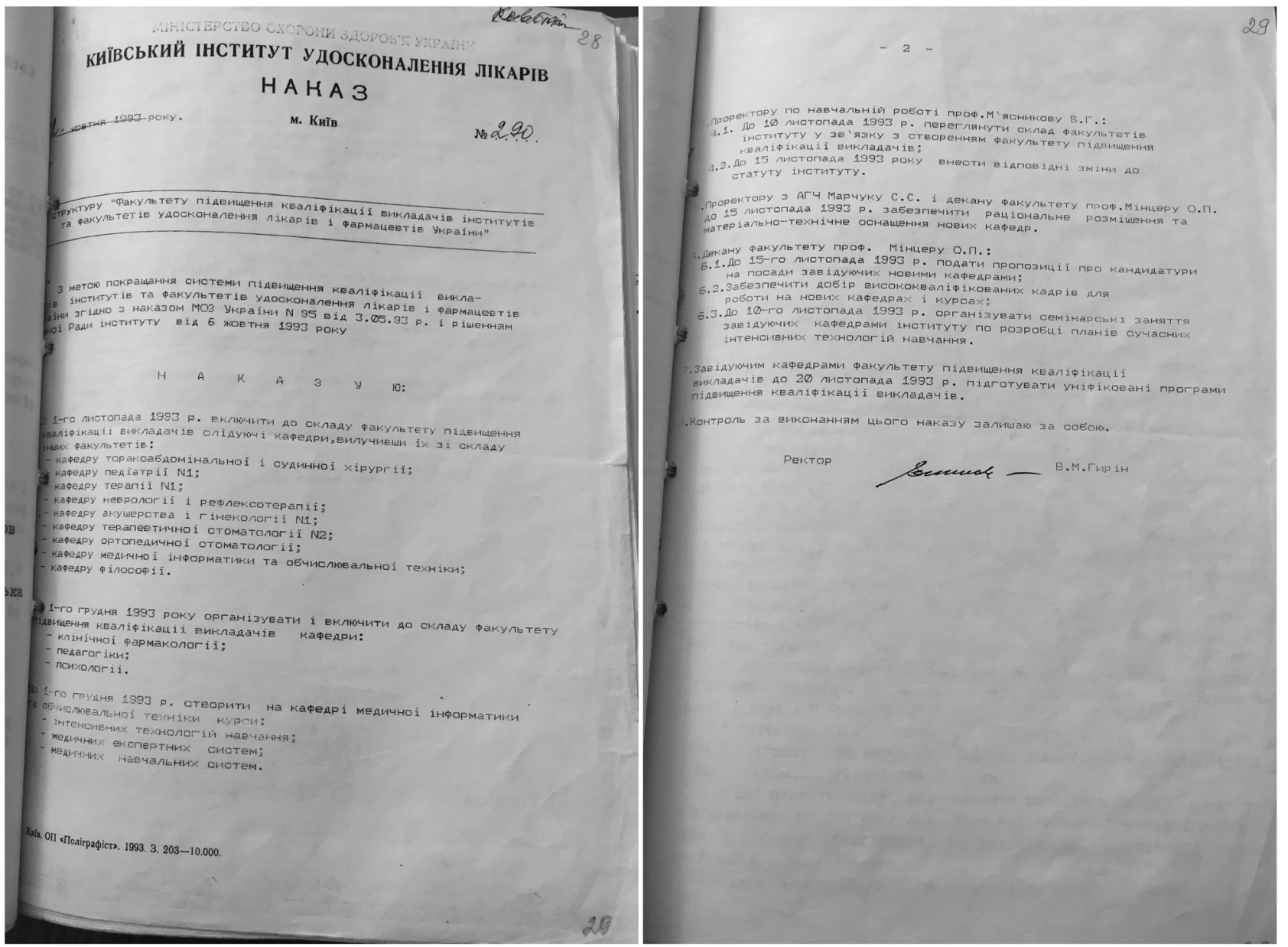

Рис. 1. Наказ про створення факультету ПКВ 
диференціацію, індивідуалізацію, запровадження дистанційних, інформаційно - комунікаційних технологій навчання;

- створення адаптивних, міждисциплінарних і трансдисциплінарних програм підвищення кваліфікації НПП системи післядипломної освіти.

Починалась історія факультету в жовтні 1993 року, коли з метою покращання системи підвищення кваліфікації викладачів інститутів і факультетів удосконалення лікарів і фармацевтів України відповідно до наказу МОЗ України від 03.05.1993 № 95 та рішення Вченої ради Київського інституту удосконалення лікарів від 06.10.1993 було створено факультет підвищення кваліфікації викладачів (наказ від 22.10.1993 № 290). До складу факультету, що розпочав свою роботу з 01 листопада, входило 9 кафедр, ще три кафедри необхідно було створити протягом місяця (рис. 1).

Деканом новоствореного факультету став його ідейний натхненник - завідувач кафедри медичної інформатики професор О. П. Мінцер, який очолював факультет у 1993 - 2005 роках. Наступними деканами стали: в 2005 - 2015 роках — завідувач кафедри гематології та трансфузіології професор С. В. Видиборець; з 2015 року — професор кафедри медичної інформатики д.б.н. доцент Л. Ю. Бабінцева.

Натепер до складу факультету ПКВ входять 10 кафедр: гематології та трансфузіології; іноземних мов; клінічної лабораторної діагностики; медичної інформатики; патологічної та топографічної анатомії; педагогіки, психології, медичного та фармацевтичного права; променевої діагностики; радіології; судової медицини; філософії.

Сім із них - опорні в системі післядипломної медичної освіти за 12 спеціальностями. На п’яти кафедрах проводиться навчання лікарів-інтернів.

Щорічно на кафедрах факультету навчається понад 2600 слухачів на 32 клінічних базах. Серед яких для виконання основної мети факультет щорічно забезпечує підвищення кваліфікації біля 700 науково-педагогічних працівників і наукових співробітників України.

В педагогічному процесі науково-педагогічні працівники факультету використовують новітні інформаційні та педагогічні технології, зокрема дистанційне навчання, індивідуальне навчання, самонавчання, проблемно-орієнтоване навчання, навчання на робочому місці. Вдало застосовуються системи управління навчанням - Moodle та Ilias. 32017 року розпочалися дослідження по впровадженню SMART навчання.

Важливим напрямом наукової та інноваційної діяльності на факультеті стала підготовка здобувачів наукового ступеню.

Чотири кафедри факультету (іноземних мов, медичної інформатики, педагогіки, психології, медичного та фармацевтичного права, філософії) забезпечують виконання освітньої складової підготовки здобувачів наукового ступеню відповідно до постанови КМУ від 23.03.2016 № 261. Розроблено та впроваджено навчальні плани та програми нормативних і вибіркових дисциплін.

Достатньо широкий спектр спеціальностей обумовлює основні наукові напрями досліджень:

- Інформатизація охорони здоров’я та медичної освіти;

- Забезпечення сучасного трансферу знань;

- Оптимізація трансфузіологічного забезпечення;

- Судово-медичне оцінювання вогнепальних ушкоджень тіла та одягу;

- Сучасна патоморфологічна діагностика та встановлення клініко-морфологічних відповідностей при різних захворюваннях;

- Оптимізація променевої діагностики та променевої терапії;

- Дослідження застосування спеціальної термінології та еквівалентів її перекладу у формуванні рівня компетентності лікаря;

- Розроблення стратегії підготовки фахівців із лабораторної медицини відповідно до Європейських вимог.

Сьогодні НПП кафедр факультету працюють над такими тематиками:

- кафедра гематології та трансфузіології: “Вивчення закономірностей формування та удосконалення методів діагностики хронічних лімфопроліферативних, мієлопроліферативних захворювань і депересій кровотворення та оптимізація їх лікування і трансфузіологічного забезпечення”;

- кафедра іноземних мов: “Дослідження професійних аспектів використання спеціальної термінології і еквівалентів її перекладу у формуванні рівня компетентності лікаря (на базі спеціальності «Неврологія»)";

- кафедра клінічної лабораторної діагностики: “Аналіз сучасного стану та розробка стратегії підготовки фахівців з лабораторної медицини відповідно до Європейських вимог”; 
- кафедра медичної інформатики: “Розробка алгоритмів інформаційно-аналітичних процесів з видобування нових знань для оптимізації систем медичної освіти і управління медичною галуззю”; - кафедра патологічної та топографічної анатомії: “Наукове обгрунтування сучасної патоморфологічної діагностики та встановлення клініко-морфологічних відповідностей при різних захворюваннях";

- кафедра педагогіки, психології, медичного та фармацевтичного права: “Формування ключових професійних та загально гуманітарних компетенцій лікаря: педагогічний, психологічний, юридичний аспект”;

- кафедра променевої діагностики: “Алгоритм променевої діагностики при вторинній адентії та планування дентальної імплантації”;

- кафедра радіології: “Оптимізація променевої діагностики і променевої терапії раку передміхурової залози";

- кафедра судової медицини: “Вогнепальна травма: морфологічні, медико-криміналістичні особливості ушкоджень та критерії їх утворення”;

- кафедра філософії: “Філософські засади медичної теорії та практики”.

На факультеті працюють: 6 експертних проблемних комісій, 3 спеціалізовані вчені ради за 7 спеціальностями; наукова школа професора О. П. Мінцера та наукова школа, що розвивається - професора В. Д. Мішалова.

Серед інших важливих здобутків факультету слід відмітити видання науково-практичних журналів, що входять до різних наукометричних баз, а три 3 них до переліку видань МОН України: “Медична інформатика та інженерія”, "Гематология. Трансфузиология. Восточная Европа”, “Лабораторная диагностика. Восточная Европа”, “Променева діагностика, променева терапія”, “Український радіологічний журнал”, “Судово-медична експертиза” та інформаційноаналітичний бюлетень “Радіологічний вісник”.

Учені факультету плідно співпрацюють з колегами професійних співтовариств: Міжнародна академія інформатизації, Європейська асоціація радіологів, Комітет освіти; Європейська асоціація фахівців ядерної медицини; Всесвітня федерація українських лікарських товариств (СФУЛТ); Європейське товариство радіаційних онкологів; Міжнародний комітет Червоного Хреста; Ягелонський університет (Республіка Польща); Університет імені Людвіг Максиміліана (Німеччина); Асоціація радіологів
Північної Америки; Асоціація сімейних лікарів Баварії тощо.

Візитівкою факультету стало функціонування з 2011 року всеукраїнського з міжнародною участю віртуального Інтернет-семінару “Інноваційні процеси в медицині та медичній інформатиці”. Семінар призначений для лікарів, провізорів, НПП ВНЗів України та інших. Участь у семінарі безкоштовна. Причому активна участь у семінарі надає учасникам безперервного професійного розвитку відповідно до наказу МОЗ України від 07.07.2009 № 484, п. 9 - 2 бали. Взяти участь у семінарі дуже просто - необхідно зареєструватися на порталі http://www.inmeds.com.ua.

Факультет підвищення кваліфікації викладачів безперервно розвивається. Продовжують удосконалюватися всі процеси управління якістю діяльності кафедр і деканату факультету. Відмітимо деякі важливі події останніх років:

- розроблення технології медичного електронного паспорту громадянина України та концепції інформатизації охорони здоров’я України;

- відкриття та функціонування в центрі симуляційних методів навчання Кабінету лабораторної медицини. Можливості кабінету дозволяють не тільки проводити навчання на сучасному обладнанні, але й виконувати наукові дослідження;

- адаптація та впровадження систем управління навчанням - Moodle та Illias;

- проведення перших науково-практичних семінарів і майстер-класів із сучасних питань патологічної анатомії;

- розроблення принципів використання комунікаторів у практичній охороні здоров'я; здійснення пілотного впровадження комунікаторів у невідкладній медицині;

- функціонування англомовного клубу «Спілкуйся англійською!» (English Speaking Club), де всі бажаючі науково-педагогічні працівники та інші працівники академії вдосконалюють навики з усного мовлення;

- проведення перших науково-практичних семінарів із безоплатної вторинної правової допомоги.

Можна багато та змістовно розповідати про діяльність кожної кафедри факультету ПКВ, його працівників, оскільки головне надбання — це досвідчені висококваліфіковані професіонали своєї справи. Проте, завершуючи цей нарис зазначимо на майбутніх завданнях факультету, що відображено в його місії та баченні діяльності. 
Місія факультету ПКВ: системне підвищення кваліфікації науково-педагогічних працівників для забезпечення високої якості освіти на основі корпоративного управління, трансляції світового та національного досвіду шляхом постійного врахування запитів кінцевого користувача освітніх і наукових послуг.

Бачення — лідер у підвищенні кваліфікації НПП в Україні, що забезпечує якісне вдосконалення професійної майстерності НПП, реалізацію їхнього безперервного професійного розвитку.

Базовим підрозділом заснування в жовтні 1993 року факультету підвищення кваліфікації викладачів стала кафедра медичної інформатики та обчислювальної техніки (нині - кафедра медичної інформатики). Оскільки весь 25-річній шлях факультету пов'язаний саме з розвитком і здобутками цієї кафедри представимо їх.

Кафедра медичної інформатики створена у 1986 році згідно з наказом від 02.01.1986 № 1 ГУУЗ Міністерства охорони здоров'я (МО3) колишнього СРСР відповідно до рішення Всесоюзної наради активу робітників МОЗ щодо прискорення науково-технічного прогресу. Спочатку кафедра мала назву медичної інформатики та обчислювальної техніки, з 1996 року — медичної інформатики. 31999 по 2015 роки до складу кафедри входив курс педагогіки та психології. Кафедра являється опорною в системі післядипломної медичної освіти (рис. 2).

Ініціатором створення першої кафедри медичної інформатики не лише в Україні, а й на теренах колишнього СРСР став відомий учений, доктор медичних наук професор, заслужений діяч науки і техніки України, дійсний член Міжнародної академії інформатизації та Української академії інформатики Мінцер Озар Петрович, який і нині її очолює.

Історія розвитку кафедри, як і самої науки інформатики, поки ще коротка, але дуже насичена яскравими подіями. За період свого існування кафедра стала однією з провідних в Україні.

За період існування на кафедрі пройшли підготовку понад десять тисяч слухачів, серед яких майже половина практичні лікарі. Також навчалися наукові співробітники та науково-педагогічні працівники закладів вищої медичної освіти України. Короткотривалі цикли на кафедрі пройшли понад 15 тисяч інтернів і слухачів суміжних циклів. Силами професорсько-викладацького складу створена автоматизована база даних, де зберіга- ється інформація про всіх слухачів, які навчалися на кафедрі.

НПП кафедри проведено понад 300 циклів тематичного вдосконалення, серед яких такі: «Сучасні аспекти навчання з використанням інформаційних технологій», «Математичні методи оброблення інформації», «Доказова медицина», «Використання персональних комп’ютерів у медичній практиці», «Інтернет - втілення сучасних інформаційних технологій», «Інформаційні технології оброблення зображень в медицині», «Інформаційні технології в фармації», «Інформаційні аспекти передавання знань при БПР лікарів і провізорів» тощо.

Кафедра оснащена сучасними персональними комп’ютерами, що мають постійний доступ до Всесвітньої мережі Інтернет. У 2005 році за ініціативи кафедри створено науковий навчально-методичний центр дистанційної освіти (Центр ДО), оснащений потужнім сучасним обладнанням. Кафедрою та Центром ДО вперше в Україні розпочато впровадження технологій дистанційного навчання та надання телемедичних консультацій.

Стратегічна мета розвитку сучасної кафедри медичної інформатики: 1) збереження статусу провідного центру розроблення та впровадження інноваційних технологій у медичну практику та медичну післядипломну освіту шляхом постійного врахування запитів кінцевого користувача освітніх і наукових послуг; 2) забезпечення консультативної мережі 3 впровадження та застосування новітніх інформаційних технологій у практику лікаря/провізора на основі використання сучасних принципів навчання.

Згадуючи понад тридцятирічну історію кафедри, необхідно зазначити вагомий внесок у становлення кафедри перших її викладачів, серед яких були: відомий учений доктор медичних наук професор Уваренко А. Р. (працював з 1988 по 2004 рр.), доктор фізико-математичних наук професор Чалий К. О.; доценти: Бутенко Л. М., Карпенко Л. М., Трушин Е. П., Шекунов А. В., Задорожна I. К., Спітковський А. І., Курчатов Г. В., Платонов С. О., Янченко Г. М., асистенти: к.б.н. Ватліцов Д. В., Нікольський О. І., Гемба В. М.

Сучасна кафедра медичної інформатики забезпечує щорічно проведення понад двадцяти циклів післядипломного навчання з медичної інформатики та кібернетики, математичного оброблення статистичних даних медичних досліджень, застосування новітніх інформаційних технологій і технологій передавання знань тощо. 
Кожні 5 років оновлюється та видається Уніфікована програма післядипломного навчання лікарів і провізорів «Медична інформатика та кібернетика в охороні здоров'я та медицині» (остання редакція в 2017 році).

У 2016 році відповідно до вимог закону України «Про вищу освіту» для підготовки докторів філософії (PhD) в аспірантурі кафедрою розроблено дванадцять нових навчальних планів і програм та відповідні методології викладання з нормативних навчальних дисциплін «Сучасні інформаційні технології у науковій діяльності та біостатистика» та «Управління науковими проектами (аналіз наукових проблем із точки зору отримання грантів)», дисциплін за вибором «Математичне моделювання в медицині та біології» та «Доказова медицина».

Наукові, педагогічні, технологічні й організаційні інновації кафедри є свідченням її потужного творчого потенціалу. Багато результатів роботи кафедри супроводжує слово «вперше».

На кафедрі постійно розробляються та впроваджуються нові технології. Так, лише за останні п’ять років серед науково - технологічних інформаційних інновацій слід назвати створення дистанційної системи оцінювання рівня знань у післядипломній медичній та фармацевтичній освіті; системи мультиваріантного дистанційного навчання лікарів та провізорів; медичного електронного паспорту громадянина України; обгрунтування автоматизованого робочого місця педагога з фармацевтичних дисциплін; наукове обгрунтування електронного паспорту слухача в системі післядипломної медичної освіти; застосування експрес - методу кірліан-графічної оцінки функціонального стану організму людини; обгрунтування до впровадження методу “Онкотест WM-01” в задачах скринінгу злоякісних пухлин; розроблена типова платформа для використання телевізійних каналів передачі інформації тощо.

Кафедра вперше в Європі провела сеанс ДН з проблем діагностики та лікування туберкульозу за участю вчених та фахівців США, Словаччини, Польщі та України. 3 боку України прийняли участь фахівці НМАПО імені П.Л. Шупика та Запорізького ДМУ, Інституту фтизіатрії та пульмонології АМН України.

Знову ж таки вперше в Україні кафедрою здійснена дистанційна перевірка знань керівників лікувальних закладів, розроблена типова платформа для використання телевізійних каналів передачі інформації.

Запропоновано систему типових навчальних планів з безперервного професійного розвитку (БПР) викладачів, сценарій проведення

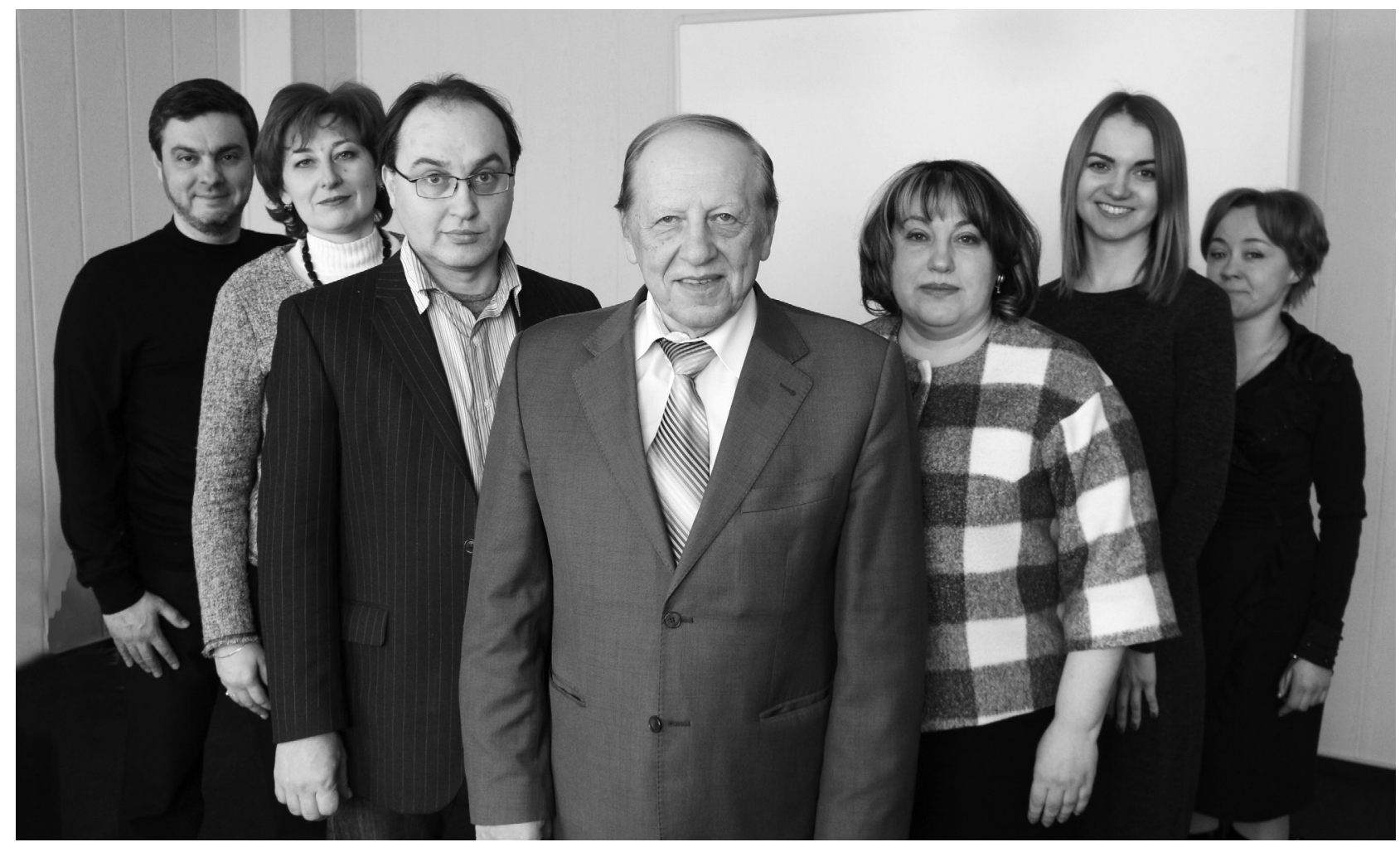

Рис. 2. НПП кафедри медичної інформатики, 2018 рік 
підвищення кваліфікації лікарів і провізорів за допомогою технологій дистанційного навчання. Спільно 3 кафедрою стоматології вперше проведений передатестаційний очно-заочний цикл зі стоматології з елементами дистанційного навчання для фахівців - стоматологів Закарпатської області (2007 р.). В рамках циклу проведений дистанційний контроль знань слухачів. 32007 року розпочата робота щодо створення монотематичних навчальних відеофільмів. Підготовлені нормативи дистанційного навчання в післядипломній медичній (фармацевтичній) освіті. розроблена та подана до МO3 України Концепція щодо визначення якості БПР на основі концепції кредитів. 3 урахуванням положень Концепції МОЗ України виданий наказ від 07.07.2009 № 484 «Про затвердження змін до Положення про проведення іспитів на передатестаційних циклах».

Отримано повноцінний доступ через Інтернет до міжнародних бібліографічних баз наукових публікацій медико-біологічного профілю. В рамках проекту HINARI Всесвітньої організації охорони здоров’я НМАПО отримала безкоштовний доступ до одного з найбільших у світі зібрань медико-біологічної літератури від видавництв Elsevier Science, Springer Verlag та електронних бібліотек BioMedCentral, Cochrane Collaboration та багатьох інших.

На кафедрі постійно створюються та впроваджуються нові технології. Так, лише за останні п’ять років серед науково-технологічних інформаційних інновацій слід назвати створення системи мультиваріантного дистанційного навчання лікарів і провізорів; розробку системи дистанційного оцінювання знань слухачів; обгрунтування автоматизованого робочого місця педагога з фармацевтичних дисциплін; наукове обгрунтування електронного паспорту слухача (портфоліо) в системі післядипломної медичної освіти; застосування експрес-методу кірліан-графічної оцінки функціонального стану організму людини, розвиток нормативно правової бази з впровадження сучасних інформаційних технологій у медичну практику та медичну освіту. Також - мобільне навчання; конструктивна педагогіка; автоматизовані адаптивні системи контролю знань; застосування комунікаторів тощо. Важливе значення мають роботи кафедри по реалізації науково-практичного співробітництва шляхом створення віртуальних науково - навчально - виробничих комплексів. Подібні проблемно-орієнтовані комплекси створено з науково дослідними інститутами НАН України, а також приватними компаніями для реалізації державно-приватного партнерства.
Серед науково-педагогічних інновацій привертає увагу ряд розробок, що вперше запропоновані в Україні, а саме: впровадження технологій організації сучасних наукових проектів: віртуалізація та інтеграція досліджень тощо; створення моделі процесу сучасної актуалізованої адаптивної освіти; розробка системи навчальної допомоги у викладанні розділів щодо фінансування закладів охорони здоров’я на кафедрах управління охороною здоров’я в медичних вищих навчальних закладах України; принципи дистанційного передавання медичних знань. Підготовлено нормативи дистанційного навчання в післядипломній медичній (фармацевтичній) освіті. Ініціалізовано адаптацію та впровадження інформаційних систем - репозитарію (DSpase), систем управління навчанням (LMS) - систем Moodle та Ilias.

Останніми роками на кафедрі виконувалися такі науково-дослідні роботи: «Розробка алгоритмів інформаційно-аналітичних процесів з видобування нових знань для оптимізації систем медичної освіти й управління медичною галуззю», «Інформаційні технології в стратегії збереження та відновлення репродукції людини», «Теоретикометодологічне обгрунтування інформаційного моніторингу фармацевтичного ринку в забезпеченні здоров’я населення», «Теоретичне обгрунтування засад створення систем отримання, оброблення та передавання медичних знань за допомогою інформаційно-комунікативних та інформаційнокогнітивних технологій».

Продовжено створення електронної бази знань 3 медицини та фармації у форматі «Єдиного медичного простору». Розпочато дослідження в принципово новому напрямі - «Системна біологія та системна медицина».

НПП кафедри тільки за останні три роки опубліковано 152 роботи, у тому числі 3 монографії, 5 методичних рекомендацій, отримано 3 патенти на винахід, 2 навчальних посібника, 4 нововведення, а також 135 статей та тез, у тому числі в закордонних журналах - 11, в наукометричних журналах - 49. Зроблено доповідей на з’їздах 57, у тому числі міжнародних - 29.

32006 р. відроджено спеціальність 14.03.11 “Медична та біологічна інформатика і кібернетика” (медичні та біологічні науки), при НМАПО імені П.Л. Шупика створено спеціалізовану вчену раду Д 26.613.10 по захисту дисертацій на здобуття наукового ступеня доктора наук (голова 
- професор О. П. Мінцер) і відкрито аспірантуру

з цієї спеціальності.

32008 року видається науково-практичний журнал «Медична інформатика та інженерія» (головний редактор - професор О. П. Мінцер), що має статус видання МОН України та включено до міжнародних наукометричних баз Index Copernicus, Ulrichs Web, Directory of Open Access Journals, Google Scholar.

3 червня 2011 року функціонує Всеукраїнський із міжнародною участю віртуальний Інтернетсемінар «Інноваційні процеси в медицині та медичній інформатиці».

З 2014 року в НМАПО імені П.Л. Шупика під керівництвом професора О.П. Мінцера функціонує наукова школа «Медична та біологічна інформатика і кібернетика».

Кафедра стала ініціатором створення Всеукраїнської громадської організації «Асоціація спеціалістів з медичної інформатики, статистики та біомедичної техніки», разом з якою щорічно проводить науково-методичні конференції з міжнародною участю «Інформаційні технології в охороні здоров'я та практичній медицині». Активно співпрацює зі світовим співтовариством за програмою створення єдиного медичного та освітянського простору, з питань застосування новітніх інформаційних технологій у практичній медицині. Неодноразово брала участь у міжнародних виставках, симпозіумах, семінарах та конференціях, де представляла свої розробки, за що відзначено почесними дипломами.

31999 по 2015 роки до складу кафедри медичної інформатики входив курс педагогіки та психології, що був започаткований у 1995 р., коли за наказом ректора КДІУЛ у складі факультету підвищення кваліфікації викладачів була створена кафедра педагогіки та психології. Перший завідувач кафедри та іï засновник - доктор педагогічних наук, професор М. В. Черпінський.

На початку своєї діяльності (вересень-грудень 1995 р.) кафедра забезпечувала викладання психолого-педагогічного модулю циклу «Сучасні аспекти навчання в медицині», організованого кафедрою медичної інформатики та обчислювальної техніки, а в січні 1996 р. стала проводити самостійні цикли. Співробітники підрозділу за 16 років провели понад 120 циклів тематичного вдосконалення, де підвищили психолого-педагогічну кваліфікацію близько 2000 викладачів. Усього затверджено 11 навчальних планів для циклів тематичного вдосконалення викладачів. Для аспірантів проводились цикли - «Основи педагогіки і психології», для інтернів - «Основи практичної медичної психології у діяльності лікарів». Короткострокові курси пройшли понад 5 тисяч інтернів і слухачів суміжних циклів. 32016 року відновлено як самостійну кафедру педагогіки, психології, медичного та фармацевтичного права.

Науково-педагогічна робота кафедри є соціально значущою, про що свідчить постійний інтерес до неї з боку засобів масової інформації та чисельні інтерв’ю на сторінках газет і журналів, на телебаченні.

Серед сучасних стратегічних напрямів роботи кафедри виділимо такі: впровадження дистанційних форм підготовки лікарів і провізорів; розробка й обгрунтування методів і засобів підготовки лікарів до ефективної професійної діяльності; впровадження принципів доказової медицини в організацію наукової діяльності; розроблення питань якості та індивідуалізації освіти; впровадження технологій телемедицини; дослідження 3 питань автоматизованих атестаційних і навчально-контролюючих систем, електронної медичної документації та технології електронної медичної паспортизації; розробка і впровадження концепцій єдиного медичного освітнього простору та навчання на робочому місці.

Основні пріоритети розвитку кафедри медичної інформатики такі: впровадження систем управління навчанням, що є етапом імплементації технологій дистанційного персоналізованого адаптивного навчання та динамічного моніторингу якості отриманих знань; створення школи з системної біології та системної медицини; застосування принципів холістичного підходу до процесу навчання та проведення біомедичних досліджень. 